\title{
False Sincerity: College Students' Ritualistic Praise from the Perspective of Interactive Ritual Chains
}

\author{
Xiyun Zhang \\ School of international education, Shandong University, Jinan, China \\ 201900360008@mail.sdu.edu.cn
}

\begin{abstract}
In the modern society where the pressure of interpersonal communication is increasing, the ritualistic interactions represented by mutual praise reinterprets the interpersonal communication behavior of youth groups to some extent. In traditional interpersonal interaction, the connotation of sincerity, affirmation and identification represented by "praise" has been deprived and replaced. According to the needs of social interaction and individual emotional needs, college students have given new connotation to "praise", showing a changing trend from sincere praise to deliberate flattering. Based on this, this paper puts forward the concept of "ritualistic praise", and analyzes the causes and influences of this phenomenon from the perspective of interactive ritual chains, to get a glimpse of the emotional life patterns of young people in the context of modern interpersonal communication.
\end{abstract}

Keywords: Interactive Ritual Chains; Ritualistic Praise; Interpersonal Communication; Emotional Model.

\section{Introduction}

With the development of society, the pressure of interpersonal communication among people in the modern era is increasing, and the handling of interpersonal relationship emphasizes more and more on emotional interaction and association. The ritualistic interaction represented by mutual praise reinterprets the interpersonal behavior of young people to a certain extent. Among the youth, the phenomenon of recognizing ritualistic praise appears, and even becomes the consensus of communication among young peers, which is particularly obvious among the college students. Ritualistic praise among college students often appears in daily communication. By studying this microscopic phenomenon, this paper discusses why false sincerity exist from the perspective of interactive ritual chains.

\section{Literature Review}

\subsection{Interactive Ritual Chains and Ritualistic Interaction}

According to Deng Xin's research, from the perspective of interactive ritual chains theory, Collins' interpersonal interaction is a ritual practiced by participants under the common belief. The core of interactive ritual chains is the interactive rite. The so-called interactive rite refers to the face-to-face interpersonal communication that may happen at any time in a small scope. [1]

Ritual itself is a word of living, but people outside the academic field are more accustomed to regard it as a large-scale ceremonial activity. Collins thinks that the interactive ritual chains model has more general significance, and he prefers to call it a mutual concern mechanism or an emotional linkage mechanism. This study focuses on Collins' deconstruction and definition of "ritual", and pays attention to the fundamental academic meaning of "ritual", that is, ritual is the most common ritualistic communication between people in real life. The existing academic research focuses on analyzing the interactive ritual chains theory and its theoretical basis, or analyzing the common online phenomena in current society by adopting the interactive ritual chains theory. So far, seldom has there been literature that analyzes the ritualistic phenomenon of daily interpersonal communication from the perspective of interactive rituals chain. 


\subsection{Interaction Chains and Ritualistic Praise}

In this paper, the concept of "ritualistic praise" is put forward. At present, papers related to ritualistic praise have not been found yet. Studies on daily phenomena such as "business-like flattery" and "mutual boasting" tend to focus on the online "mutual praise groups". Such literature basically analyzes the internal structure and interactive features of the "mutual praise groups" from the perspective of journalism and communication. This study focuses on the fact that "praising" is a ritualistic interpersonal interaction, creatively puts forward the concept of "ritualistic praise", and deeply analyzes the nature of this daily interpersonal behavior and its emotional linkage mechanism from the perspective of interactive ritual chains.

\section{Theoretical Framework}

The interactive ritual chains theory was put forward by American contemporary sociologist Randall Collins. The so-called interactive ritual chains refers to the chain structure formed by the connection of numerous interactive rituals which take place in specific "opportunities". Interactive rituals are the core of interaction ritual chains. Ritual refers to the face-to-face interpersonal communication that takes place in real time in a small scale. In this theory, emotion, an irrational factor, is the core motivation and important product of interpersonal communication in daily life. The core view of this theory is that in the process of ritualistic interaction, the ultimate goal of people's behavior is to pursue the maximization of emotional energy [2]

\section{Research Methods}

This research selected eight interviewees by stratified sampling, and conducted semi-structured interviews for two months. The interview materials of the eight interviewees were collected through the combination of online and offline interviews, and no unexpected cases occurred during the interviews, which ensured the credibility and richness of those interviews. Considering the comprehensiveness and sustainability of the research, the interviewees are selected in consideration of different levels of schools. The interviewees' information is as follows:

Table 1. Basic information of interviewees

\begin{tabular}{|c|c|c|c|c|}
\hline & Age & Occupation & College name & $\begin{array}{c}\text { Level of his/her interpersonal } \\
\text { relationship }\end{array}$ \\
\hline A & 20 & college student & Shandong University & good \\
\hline B & 21 & college student & Peking University & so-so \\
\hline C & 23 & college student & Shandong University & good \\
\hline D & 20 & college student & Renmin University of China & bad \\
\hline E & 23 & college student & Nanjing University & good \\
\hline F & 25 & college student & Central Conservatory of Music & good \\
\hline G & 21 & college student & $\begin{array}{c}\text { China University of Mining and } \\
\text { Technology }\end{array}$ & so-so \\
\hline H & 23 & college student & Nantong University & good \\
\hline
\end{tabular}




\section{Analysis of Results}

\subsection{Emotional Energy: The Interactive Core of Ritualistic Praise}

In the context of traditional interpersonal communication, praise means that the praise initiator recognizes and agrees with the behavior or words of the complimented person from the heart, and the behavior of praise is voluntary and active. Praise, as one of the basic principles of social communication and interpersonal relationship maintenance, conveys the concern and appreciation among people in social environment. Its mechanism of action is a two-way interaction: the complimented person gets emotional energy from the affirmation of the praise initiator, and the praise initiator makes emotional contribution while simultaneously obtaining encouragement and inspiration to some extent. Emotion energy becomes the link between both sides and the interactive core of ritualistic praise. The emotional connection between them is constructed by the emotional energy brought by praise, and maintained by the sustainability and transformability of emotional energy.

Interviewee B: "In my conversation with classmates, I did find that praise and compliment would make our conversation smoother. This is also a kind of business-like flattery, which brings us closer quickly, and both sides become very happy and reduce some conflicts.

Interviewee C: "Although I sometimes wonder if others praise me sincerely, I am still very happy to hearthose compliments, especially when I meet others in the morningand hear those compliments, I feel that I will be in a good mood all day. I think it is necessary for classmates or friends to praise each other. This kind of praise has the nature of goodwill and encouragement, which makes us more confident. "

Ritualistic praise has become the carrier of emotional interaction and resonance among college students, and can also make college students possess a stronger sense of belonging and identity in interpersonal interaction. Ritualistic praise can often bring positive feelings, such as self-confidence and pleasure, to both interactive parties, and then generate emotional energy, which can effectively promote communication between both parties and promote the formation and stability of good interpersonal relationships. This kind of "emotional energy" flows from one interactive situation to the next in the chains of interactive rituals. The value of this emotional energy lies in the reciprocity, mobility and transferability of both parties.

However, in the long run, those who are praised tend to rely on the energy and self-confidence brought by ritualistic praise. In this way, the individual's emotional drive is weakened, and it will even decline with the disappearance or reduction of this ritual.

Interviewee A: "Every time when I meet one of my friends, I would try my best to praise her. Sometimes I would say that her clothes were really beautiful, or her make-up was so beautiful that day. She was very happy after hearing the praise. However, after some time, our relationship faded again. Later, I gradually stopped taking the initiative to contact her."

Interviewee D: "In fact, when someone praises me, I care whether it's because I really did a good job or it's just a courtesy compliment, or a flattery. Sometimes I even wonder if he/she wants something from me."

Thus, the influence of ritualistic praise is not always positive. Because of the individual's need for emotional energy, he hopes for positive affirmation such as praise and compliments, but because of such praise, the individual has negative emotions such as doubt, which may increase the emotional burden. In addition, the maintenance effect of ritualistic interaction represented by ritualistic praise on interpersonal relationship is limited, and it depends on both sides. The collapse of the interaction chain maintained by ritualistic praise is very likely to lead to the collapse of interpersonal relationship.

\subsection{Emotional Socializing: Ritualistic Praise as a Tool}

Interviewee G: "I usually like to praise my classmates when I greet them, because praising others can promote our relationship almost without paying any cost, and saying "you are beautiful" and "you 
are amazing "can make the other party happy. Usually, people will praise back. It is much simpler and more cost-effective than other methods of maintaining interpersonal relationships."

Interviewee H: "I used to praise others mostly out of sincere appreciation and admiration, but now I often have to praise others without such intentions. I have been used to maintaining interpersonal relationships in this way, by praising others more and more frequently."

It can be concluded that individuals expect the authenticity and sincerity of the received feelings. However, ritualistic praise, as a low-cost social input, or even a social tool, arises from the emotional needs in the increasingly modern society. Obtaining emotional energy and maintaining interpersonal relationships often become the most common potential motives for ritualistic praise, and the praise initiator often does not carefully consider whether the praise words are refined and meet the expectations of the praised person.

Interviewee E: "Sometimes praising others may be counterproductive and may make others think it is a mockery. For example, my grades are very good. Every time my classmates see me studying, they praise me for my hard work and diligence, which makes me feel that my good grades are obtained by spending all my time studying. I feel that they have not seen my personal qualities such as my indepth thinking ability, which sometimes makes me feel very uncomfortable. "

In ritualistic praise, the praise initiator sometimes expresses praise and affirmation with words that are too exaggerated and regardless of the facts, which makes both sides fall into a false emotional environment. In such cases, emotional linkage and emotional exchange are difficult to achieve, which is not conducive to the maintenance of interpersonal relationship. With the pressure of modernization, young people cannot actually get rid of the anxiety and pressure of reality, and the existence of ritualistic praise even falls into the anxiety of expecting "praising", which is very likely to further kill the upward fighting spirit and give up "what will eventually make him overcome loneliness constructively, that is, develop his own internal resources, strength and sense of direction". [3]

In ritualistic praising interactions, both parties pray for self-realization through this kind of white lie, which is not stable and normal, and cannot continue to take effect. Excessively "seeking praise" will not only lead to a lack of sense of value and gain in life, but will also make young people no longer willing to work hard to get true praise after being in too many praises, and only want to be comforted and satisfied in false praise. What's more, in order to maintain the praise ritual chain, the praised person puts his behavior under the behavioral framework that may be praised, which virtually limits the possibility of self-development.

Interviewee G: "For example, as soon as I get a new hairstyle, I would take selfies and post them on my Moments. At such times, I especially hope that others will praise my new hairstyle in their comments. I really like it when others praise my appearance, because it can temporarily relieve my anxiety about my appearance and body shape, so sometimes I will post selfies with together with words like "praise wanted'. "

It's in our nature to enjoy others' encouragement and attention, and to enjoy the happiness of being appreciated. However, as Maurice Schweitzer and Emma E. Levine said: "People's aversion to lying comes from moral judgment. Altruistic lies, though violating moral standards because of caring about others, are often considered to be more moral than honesty." Even though everyone knows that praises in ritualistic praise interactions are not all sincere and true, and sometimes they are just a white lie or a joke, but they have become a part of ritualistic interaction, because the emotional support and spiritual power people feel from praising interactions will not be damaged by knowing its falsehood.

\subsection{Emotional Alienation: Hypocrisy in Ritualistic Praise}

The essence of praise is to affirm and compliment people or things based on facts. As an external spontaneous evaluation, the meaning of praise is based on spontaneous reaction rather than pleasing others or calculating means. Its significance and value depend on its authenticity and uniqueness, and also on whether it is scarce.

Ritualistic praise skillfully satisfies people's inner desire to be praised and paid attention to, and makes college students gain recognition from it. 
In the current interpersonal communication among college students, they are always used to praising each other's characteristics or possessions in chat or communication, so as to shorten the interpersonal communication distance. The whole communication process is so circular, and the interactive chain is constructed and reconstructed in continuity and interruption. Each individual expects to enhance interpersonal communication by expressing praise, and also hopes to get praise to enjoy emotional pleasure. When the ritual chain is interrupted, the emotion is interrupted, waiting for the next reconstruction. At first, praise is a way to express true feelings, but now, the connotation of praise has changed. Over time, individuals have abandoned the basic way of human emotion linkage intentionally or unintentionally. What's more, praise has become a ritual and has been "made as a tool".

At the same time, the expression of sincere praise has gradually become ritualized, and it has become a tool or means for image building, social interaction and serving a certain purpose. It stimulates individual emotional energy and constructs interpersonal relationship. However, clapping and praising blindly and catering to classmates, friends or stakeholders will also make people lose the ability to express correct values and genuine ideas, and make sincere and natural group interaction become superficial and calculating.

One of the costs of modernity is the alienation, dilution and falsehood of emotion. When people don't treat praise sincerely, they won't really obtain positive emotional energy such as self-confidence and sense of accomplishment brought by praise. Also, it will be hard to feel the emotional energy brought by emotional connection in praise and interaction, and it's even harder to build a positive image and promote social morality by praising. The lack of true emotions and the proliferation of false feelings in youth interpersonal interaction lead to the anxiety of youth groups in emotional life in the context of modern society, and even the negation of self-individual values and the neglect and indifference of sincere interpersonal communication, thus affecting the shaping and formation of youth groups' emotional values.

\section{Conclusion}

Ritualistic praise reflects the emotional needs and value orientation of contemporary youth groups, and the psychological symptoms of youth groups behind it should be continuously tracked and further explored. It is particularly important to guide youth groups to express their emotions sincerely and correctly. By clarifying the essence of "ritualistic praise", a new cultural form of Chinese youth society, this paper provides some new perspectives and research ideas for grasping the psychological symptoms and value orientation of youth groups in the context of contemporary China and for promoting emotional education in higher education to promote the healthy development of emotional patterns of youth groups. It is hoped that this study can enrich the research content of interpersonal communication, emotional interaction and emotional education, and play a role in inspiring more valuable research.

\section{References}

[1] Deng Xin. Covered Emotional Dimension: Interpretation of Randall Collins' Interactive Ritual Chains Theory [J]. Press, 2020(08):40-47+95.

[2] Li He, Wu Mudan. Analysis of Interpersonal Communication in Wechat from the Perspective of Interactive Ritual Chains [J]. Today Media, 2016,24(11):12-13.

[3] Sun Yu. "False feelings and Hypocrisy": Youth Authenticity in Ritualistic Interaction [J]. Chinese Youth Research, 2020(09):76-82+112.

[4] Wang Ning. A Brief Discussion on the Social Mode of Emotion --Notes on the Study of Sociology of Emotion [J]. Sociological Research, 2000(04):122-125.

[5] Jiang Jianguo, Zhao Yiying. "Praise Groups": Identity Anxiety, Praise Overflow and Group Pretense [J]. Modern Communication (Journal of Communication University of China), 2020,42(02):70-75. 
[6] Wang Ying. Research on Emotional Interaction of Online Variety Show Based on Interactive Ritual Chains Theory [D]. Guangdong Technical Normal University, 2021.

[7] Zhu Hanqing. Research on Emotional Interactive Rituals of Video Blogs [D]. Suzhou University, 2020.

[8] Liu Yu. The Formation Mechanism and Governance of School Bullying from the Perspective of Emotional Interactive Ritual Chains Theory [J]. Journal of Xinyang Normal University (Philosophy and Social Sciences Edition), 2019,39(06):65-69.

[9] Wang Haixuan, Ren Yanjun. On the Phenomenon of College Students' Spiritual Communication in the Era of Media Convergence --Taking "Praise Groups" in Social Networking as an Example [J]. Media, 2019 (21):81-83.

[10] Yan Haichao. "Praise Groups" of the "Post-00" Youth: Creating Identity, Self-irony and Value Confusion [J]. Hunan Social Sciences, 2020(03):160-164. 